\title{
ANTAGONISTIC INTERACTION OF LACOSAMIDE WITH CARBAMAZEPINE AND VALPROATE IN THE MOUSE TONIC-CLONIC SEIZURE MODEL
}

\section{ANTAGONISTYCZNA INTERAKCJA LAKOZAMIDU Z KARBAMAZEPINĄ I WALPROAINIANEM W MODELU DRGAWEK TONICZNO-KLONICZNYCH U MYSZY}

\author{
Maria W. Kondrat-Wróbel ${ }^{1(B, D, F)}$, Katarzyna Załuska $^{1(B, D, F)}$, Aleksandra Walczak $^{1(B, C, F)}$, \\ Anna N. Panasiuk-Poterek ${ }^{1(B, C, D)}$, Agata Gut-Lepiech ${ }^{1(B, D, F)}$, \\ Paula Wróblewska-tuczka ${ }^{1(\mathrm{D}, \mathrm{E}, \mathrm{F})}$, Jarogniew J. Luszczki ${ }^{1,2(\mathrm{~A}, \mathrm{C}, \mathrm{D}, \mathrm{E}, \mathrm{F}, \mathrm{G})}$
}

${ }^{1}$ Department of Pathophysiology, Medical University of Lublin, Poland ${ }^{2}$ Isobolographic Analysis Laboratory, Institute of Rural Health, Lublin, Poland

Authors' contribution Wkład autorów: A. Study design/planning zaplanowanie badań B. Data collection/entry zebranie danych C. Data analysis/statistics dane - analiza i statystyki D. Data interpretation interpretacja danych E. Preparation of manuscript przygotowanie artykułu F. Literature analysis/search wyszukiwanie i analiza literatury G. Funds collection zebranie funduszy
Tables: 2

Figures: 2

References: 32

Submitted: 2018 Aug 7

Accepted: 2018 Oct 17

\section{Summary}

Background. It is estimated that approximately $1 \%$ of people worldwide suffer from epilepsy. Currently available antiepileptic drugs (AEDs) are able to control epileptic seizures in about 70\% of cases. In the remaining patients (30\%), the application of two or three AEDs in combination is necessary for effective seizure management. The goal of this work was to characterize the interaction of three AEDs: lacosamide (LCM), carbamazepine (CBZ) and valproate (VPA) at the fixed-ratio of 1:1:1 in the mouse tonic-clonic seizure model.

Material and methods. Male albino Swiss mice, after receiving a combination of LCM, CBZ and VPA, were challenged with electric current to evoke tonic hind limb extension (seizure activity). Protection of the mice from tonic-clonic seizures was assessed by isobolographic analysis to determine the type of interaction occurring between these drugs.

Results. Type I isobolographic analysis revealed that the combination of LCM, CBZ and VPA produced infra-additive (antagonistic) interaction in the mouse tonic-clonic seizure model.

Conclusions. Since the three-drug mixture of LCM, CBZ and VPA exerted an antagonistic interaction in the tonic-clonic seizure test in mice, we would caution physicians against treating epilepsy patients with this unfavorable combination.

Keywords: antiepileptic drugs, isobolography, maximal electroshock, three-drug combination, antagonism

\section{Streszczenie}

Wprowadzenie. Szacuje sie, że około $1 \%$ osób na całym świecie cierpi na padaczke. Obecnie dostępne leki przeciwpadaczkowe pozwalają na opanowanie napadów padaczkowych w około $70 \%$ przypadków. U pozostałych pacjentów z padaczką (30\%) konieczne jest zastosowanie dwóch lub trzech leków przeciwpadaczkowych w kombinacji. Celem pracy było scharakteryzowanie interakcji między trzema lekami przeciwpadaczkowymi: lakozamidem (LCM), karbamazepiną (CBZ) i walproinianem (VPA) w stałym stosunku dawek 1:1:1 w modelu drgawek toniczno-klonicznych u myszy.

Materiał i metody. Samce myszy albino Swiss, po otrzymaniu kombinacji LCM, CBZ i VPA, poddano działaniu prądu elektrycznego, aby wywołać toniczny wyprost kończyn tylnych (aktywność drgawkową). Ochronę myszy przed napadami toniczno-klonicznymi oszacowano za pomocą analizy izobolograficznej, aby określić typ interakcji zachodzącej między tymi lekami.

Wyniki. Analiza izobolograficzna typu I ujawniła, że kombinacja LCM, CBZ i VPA powodowała oddziaływanie infra-addytywne (antagonistyczne) w modelu drgawek toniczno-klonicznych u myszy.

Wnioski. Ponieważ trójlekowa mieszanina LCM, CBZ i VPA wywierała antagonistyczną interakcję $\mathrm{w}$ teście napadów toniczno-klonicznych u myszy, specjalne ostrzeżenie jest konieczne dla lekarzy, aby nie leczyć pacjentów z padaczką tą niekorzystną kombinacją.

Słowa kluczowe: leki przeciwpadaczkowe, izobolografia, elektrowstrząsy, kombinacja trzech leków, antagonizm

Kondrat-Wróbel MW, Załuska K, Walczak A, Panasiuk-Poterek AN, Gut-Lepiech A, Wróblewska-Łuczka P, et al. Antagonistic interaction of lacosamide with carbamazepine and valproate in the mouse tonic-clonic seizure model. Health Prob Civil. 2019; 13(1): 92-98. https://doi.org/10.5114/hpc.2019.81105

Address for correspondence / Adres korespondencyjny: Jarogniew J. Łuszczki, Department of Pathophysiology, Medical University of Lublin, 20-090 Lublin, Poland, e-mail: jarogniew.luszczki@umlub.pl, phone: +48 8144865 00; ORCID: Maria W. Kondrat-Wróbel https://orcid.org/0000-0001-6614-8807, Katarzyna Załuska https://orcid.org/0000-0001-5358-8889, Aleksandra Walczak https://orcid.org/0000-0003-3778-2045, Paula Wróblewska-Łuczka https://orcid. org/0000-0002-7099-1968, Jarogniew J. Łuszczki https://orcid.org/0000-0002-3059-0393

Copyright: (C) Pope John Paul II State School of Higher Education in Biała Podlaska, Maria W. Kondrat-Wróbel, Katarzyna Załuska, Aleksandra Walczak, Anna N. Panasiuk-Poterek, Agata Gut-Lepiech, Paula Wróblewska-Łuczka, Jarogniew J. Łuszczki. This is an Open Access journal, all articles are distributed under the terms of the Creative Commons Attribution-NonCommercial-ShareAlike 4.0 International (CC BY-NC-SA 4.0) License (http://creativecommons.org/licenses/by-nc-sa/4.0/), allowing third parties to copy and redistribute the material in any medium or format and to remix, transform, and build upon the material, provided the original work is properly cited and states its license. 


\section{Introduction}

Epilepsy is one of the most frequently occurring neurological diseases, affecting almost $1 \%$ of the population worldwide [1]. Pharmacotherapy with currently available antiepileptic drugs (AEDs) is the treatment of choice for patients with epilepsy. However, the application of one AED, as monotherapy, is sometimes insufficient to halt seizure attacks in epilepsy patients $[2,3]$. In such a situation, physicians prescribe two or three AEDs. The AEDs selected for combinatorial therapy are based on theoretical presumptions suggesting it is beneficial to combine AEDs with diverse molecular mechanisms of action [4]. This has been a "golden rule" followed by physicians since 2002, when this treatment method was clinically confirmed in patients with resistant epilepsy [2,3].

Recently, several favorable combinations of AEDs have been clinically confirmed [5]; however, with 25 currently licensed AEDs, there can be (theoretically) 13,800 distinct three-drug combinations. Only a few of these combinations have been clinically verified [2,3], and the efficacy of the remaining three-drug combinations have yet to be clinically established or publicly revealed. In order to aid clinicians in their choice on how to combine AEDs, preclinical studies in animal models can provide useful information on favorable combinations that could be utilized in patients with epilepsy for seizure suppression [6-10]. Several triplicate AED combinations have been found to be either beneficial, producing synergy, or neutral, with additivity determined by isobolography in an experimental animal model of epilepsy [6-9]. It is believed that synergistic interactions observed in experimental animal models of epilepsy will be similarly synergistic in humans - this is a basic concept resulting from translational study data [4].

Generally, the application of three drugs produces interactions that may be pharmacokinetic, pharmacodynamic or both [11]. Theoretically, some AED combinations may be beneficial due to a reduction of drug doses. However, it is highly likely that some AED combinations may produce unfavorable effects. Theoretical presumptions can aid physicians in selecting proper combinations of AEDs that exert a favorable interaction in mammals, and it is known that various molecular mechanisms of action contribute to the wide range of seizure suppression exerted by AEDs [4, 12].

Since induction, propagation and amplification of seizures are complex processes and, unfortunately, not fully understood, seizure suppression often requires medicating with various AEDs [4, 13]. Undoubtedly, various AEDs with diverse molecular mechanisms of action should synergistically cooperate in terms of seizure suppression [12].

The aim of this study was to continue our previous experiments and assess the type of interaction between three AEDs: lacosamide (LCM), carbamazepine (CBZ) and valproate (VPA) in the tonic-clonic seizure model in mice. To search for interaction among the AEDs, we used type I isobolographic analysis of interaction, which is considered a gold standard in the evaluation of drug properties in preclinical studies [14]. The selection of AEDs in this study was not serendipitous because two of the studied AEDs, VPA and CBZ, are widely prescribed AEDs (as first-line drugs) for patients with tonic-clonic seizures, partial onset convulsions with or without secondary generalization $[15,16]$. LCM has recently been licensed as an add-on drug for patients with partial-onset seizures with or without secondary generalization [17]. Thus, from a theoretical point of view, the combination of LCM, CBZ and VPA should likely be beneficial, offering the patients with epilepsy a suppression of tonic-clonic seizures. Moreover, the choice of these AEDs (LCM, CBZ and VPA) was considered to be ideal because the drugs in combination, due to their diverse molecular mechanisms of action, should theoretically provide maximal therapeutic effects and no or minimal side effects [18]. Thus, to confirm our hypothesis that the combination of LCM with CBZ and VPA was an "ideal" selection, we conducted experiments on male albino Swiss mice as described previously $[6,8,9,19]$.

\section{Material and methods}

Adult male albino Swiss mice (8 week-old, weighing 22-26 g) were used in this study. All experimental procedures carried out in this study were in strict accordance with the Guide for the Care and Use of Experimental Animals [20], and approved by the Local Ethics Committee (License no.: 45/2014).

LCM (Vimpat ${ }^{\circledR}$, UCB Pharma, Brussels, Belgium) and CBZ (Polfa, Starogard Gdanski, Poland) were suspended in a $1 \%$ solution of Tween 80 (Sigma-Aldrich, Poznań, Poland) in distilled water, while VPA (Sigma-Aldrich, Poznań, Poland) was dissolved directly in sterile distilled water. All three drugs (LCM, CBZ and VPA) were administered i.p., 30 min before the tonic-clonic seizures and all behavioral tests.

A rodent shocker (Hugo Sachs, type 221, Freiburg, Germany) was used to induce seizure activity in animals by a current ( $25 \mathrm{~mA}, 500 \mathrm{~V}, 50 \mathrm{~Hz}, 0.2 \mathrm{~s}$ stimulus duration) delivered via ear-clip electrodes. The seizure activity in the experimental mice manifested in the form of tonic hind limb extension. Different increasing drug doses 
were administered to animals in order to determine a variable percentage of protection from tonic-clonic seizures. Doses of drugs and their corresponding protective effects were linearly related using dose-response effect functions [21]. The anticonvulsant potency of CBZ, LCM and VPA when administered alone was expressed as median effective doses $\left(\mathrm{ED}_{50}\right.$ in $\left.\mathrm{mg} / \mathrm{kg}\right)$ of the $\mathrm{AEDs}$, protecting $50 \%$ of mice from tonic-clonic seizures. Similarly, the anticonvulsant potency of the three-drug mixture in the fixed-ratio of 1:1:1 was expressed as the experimental median effective dose $\left(\mathrm{ED}_{50 \mathrm{exp}}\right.$ value) protecting $50 \%$ of mice from tonic-clonic seizures.

Characterization of interactions among three AEDs was performed with isobolographic analysis of interaction, as described previously [6-8]. The test for parallelism of dose-response effects for LCM, CBZ and VPA was performed with the log-probit method [21]. Subsequently, we calculated median additive dose for the mixture of three AEDs at the fixed-ratio combination of 1:1:1 ( $\mathrm{ED}_{50 \text { add }}$-i.e., a dose of the mixture that theoretically protected $50 \%$ of the tested mice from tonic-clonic seizures). The equations underlying the calculations have been described previously [6-8]. Next, the anticonvulsant effects produced by the three-drug mixture of LCM, CBZ and VPA (at the fixed-ratio of 1:1:1) were evaluated and expressed as the $\mathrm{ED}_{50 \text { exp }}$ value, reflecting a dose of the mixture that protected $50 \%$ of the mice from tonic-clonic seizures.

Acute adverse effect potentials produced by the mixture of three AEDs (LCM, CBZ and VPA, applied in doses reflecting the $\mathrm{ED}_{50 \text { exp }}$ value from the tonic-clonic seizure model) were determined in three standard behavioral tests: the chimney test (assessing motor coordination), grip-strength test (assessing skeletal muscular strength) and passive avoidance task (evaluating long-term memory and learning) in experimental animals, as described elsewhere [22].

The experimentally determined $\mathrm{ED}_{50 \text { exp }}$ value from the tonic-clonic seizure model was statistically compared with its theoretical additive $\mathrm{ED}_{50 \text { add }}$ value using the unpaired Student's $t$-test. Impairment of motor coordination in mice from the chimney test was statistically analyzed with Fisher's exact probability test. Mean muscular strengths of the animals from the grip-strength test were statistically compared with Student's t-test. Median retention times from the passive avoidance task were statistically analyzed with Mann-Whitney U-test. All data were statistically analyzed with GraphPad Prism version 7.0 for Windows (GraphPad Software, San Diego, CA, USA).

\section{Results}

The experimentally-derived $\mathrm{ED}_{50}$ values for LCM, CBZ and VPA (all three AEDs administered alone) in the mouse tonic-clonic seizure model were $7.27 \pm 0.77 \mathrm{mg} / \mathrm{kg}, 14.25 \pm 0.79 \mathrm{mg} / \mathrm{kg}$, and $298.6 \pm 15.15 \mathrm{mg} / \mathrm{kg}$, respectively (results not shown). The equations for the dose-response functions, along with the test for parallelism for the respective AEDs (LCM, CBZ and VPA), are presented in Figure 1. The log-probit line for CBZ was parallel to that of VPA (Figure 1). In contrast, LCM's log-probit line was non-parallel to that of CBZ and VPA in the mouse tonic-clonic seizure model (Figure 1). The mixture of LCM, CBZ and VPA at the fixed-ratio of 1:1:1 produced anticonvulsant activity and the experimentally-derived $\mathrm{ED}_{50 \text { exp }}$ value was $140.49 \pm 11.09 \mathrm{mg} / \mathrm{kg}$ (Figure 2A). In contrast, the theoretically calculated $\mathrm{ED}_{50 \text { add }}$ value was $106.71 \pm 5.05 \mathrm{mg} / \mathrm{kg}$ (Figure $2 \mathrm{~A}$ ). With isobolography, it was found that the three-drug mixture at the fixed-ratio of 1:1:1 exerted an infra-additive (antagonistic) interaction $(\mathrm{P}<0.05)$ in the tonic-clonic seizure model in mice (Figure 2A-2C). Moreover, the evaluation of potential acute adverse effects produced by the three AED mixture (at doses reflecting the $\mathrm{ED}_{50 \mathrm{exp}}$ from the tonic-clonic seizure model) in three behavioral tests revealed that the mixture did not disturb long-term memory and learning or skeletal muscular strength in the experimental animals (Table 1). Motor coordination in mice subjected to the chimney test was the only behavior that was slightly affected. One out of eight mice displayed impairment in motor coordination (12.5\%, Table 1). However, the observed coordination deficits were not statistically significant (Table 1). 


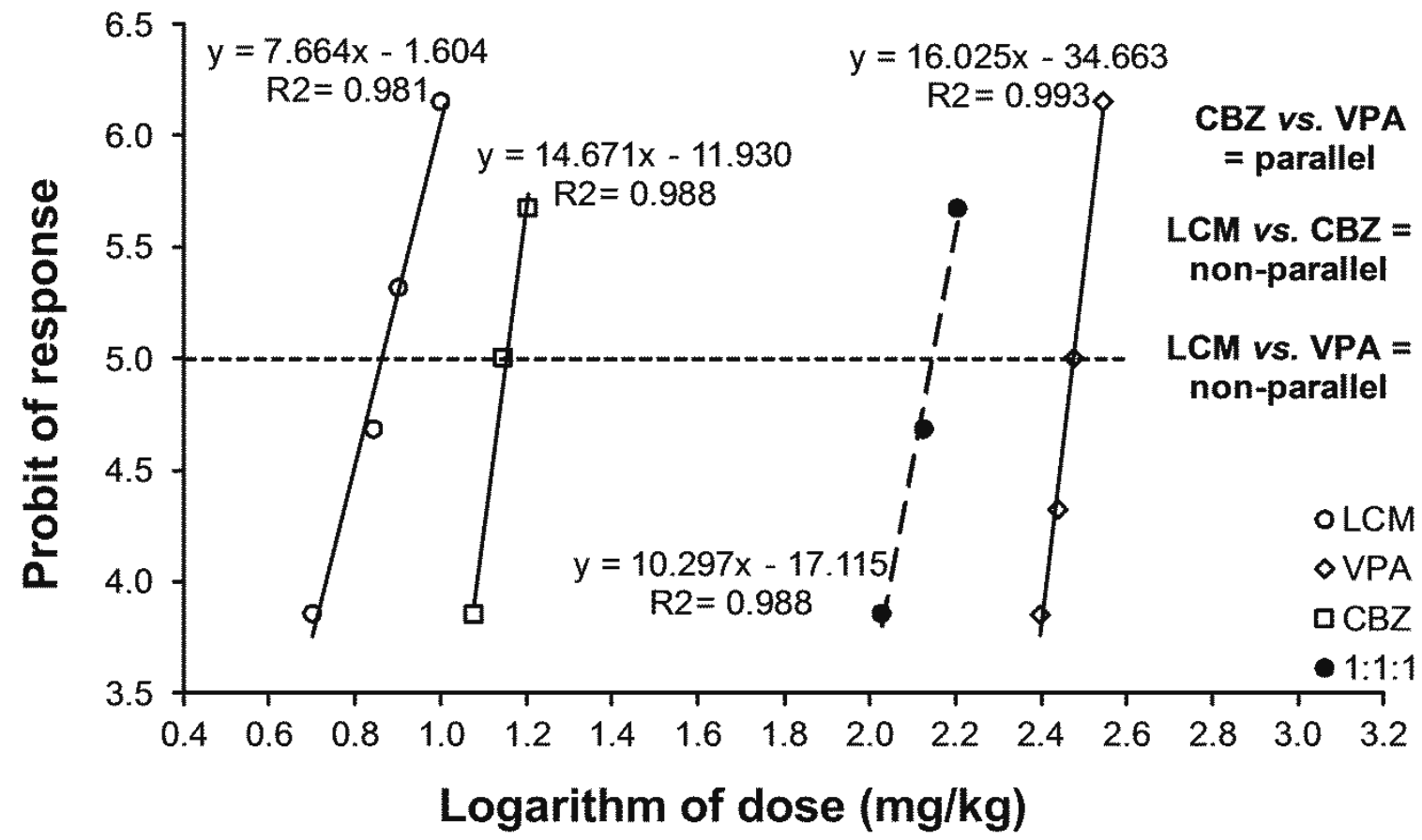

Figure 1. Dose-response functions for lacosamide (LCM), carbamazepine (CBZ), and valproate (VPA) when injected alone and in combination for the fixed-ratio of 1:1:1 in the mouse tonic-clonic seizure model

Doses of AEDs were transformed to logarithms, while their anticonvulsant effects from tonic-clonic seizures in mice were transformed to probits according to the log-probit method [21]. Linear regression functions for CBZ, LCM and VPA administered separately and in combination at the fixed-ratio of 1:1:1 are presented on the graph.
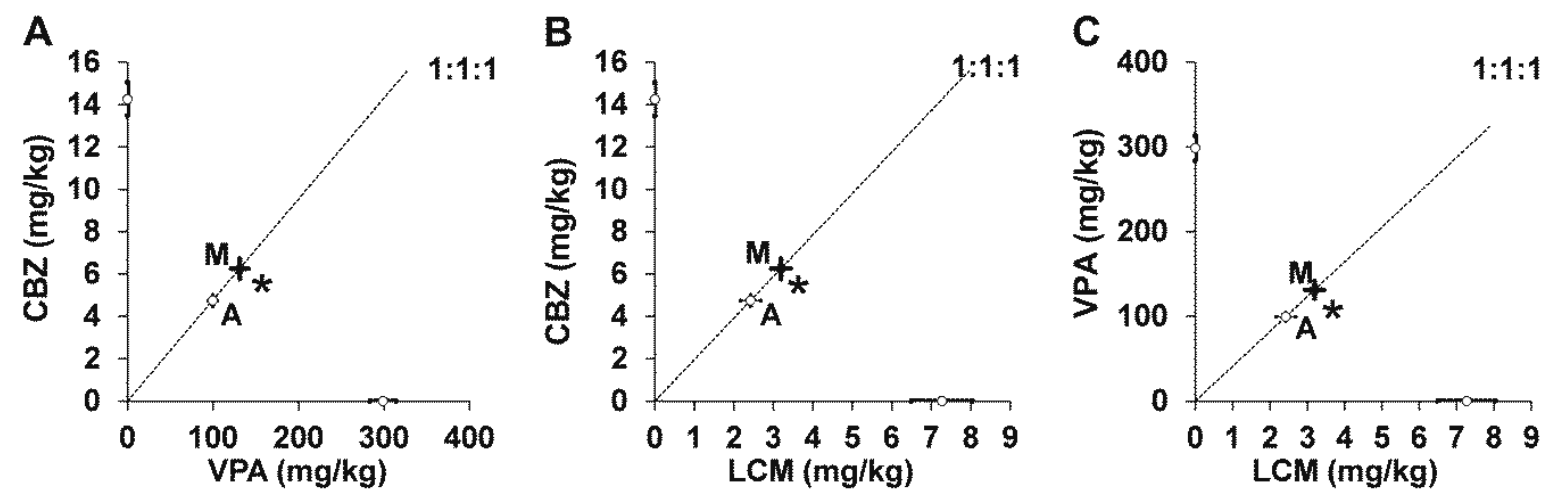

$$
E D_{50 \exp }=140.49 \pm 11.09 \mathrm{mg} / \mathrm{kg}
$$

$$
E D_{50 \text { add }}=106.71 \pm 5.05 \mathrm{mg} / \mathrm{kg}
$$

Figure 2. Isobolograms illustrating antagonistic (infra-additive) interaction among carbamazepine (CBZ), lacosamide (LCM) and valproate (VPA) in tonic-clonic seizures in mice

The $\mathrm{ED}_{50}$ values ( \pm S.E.M.) of LCM, CBZ and VPA are plotted on X- and Y-axes, respectively. Point M depicts the experimentally-derived $\mathrm{ED}_{50 \text { exp }}\left( \pm\right.$ S.E.M.) value, whereas point $A$ indicates the theoretically calculated $\mathrm{ED}_{50 \text { add }}( \pm$ S.E.M.) value, corresponding to doses of AEDs in combination that protected $50 \%$ of the mice from tonic-clonic seizures. The dotted line starting from the point $(0,0)$ and crossing through the points $M$ and $A$ reflects the fixed-ratio of 1:1:1 for the three-drug combination. The experimental $\mathrm{ED}_{50 \text { exp }}$ value of the three-drug mixture is placed significantly above the theoretically calculated $\mathrm{ED}_{50 \text { add }}$ value $\left({ }^{*} \mathrm{P}<0.05\right)$, indicating the infra-additive (antagonistic) interaction. Statistical comparison of $\mathrm{ED}_{50 \text { add }}$ and $\mathrm{ED}_{50 \text { exp }}$ values was performed by using the unpaired Student's $t$-test. 
Table 1. Influence of the three-drug mixture of lacosamide (LCM), carbamazepine (CBZ) and valproate (VPA) on skeletal muscular strength, long-term memory and motor coordination in mice

\begin{tabular}{|c|c|c|c|}
\hline Treatment (mg/kg) & Muscular strength (N) & Retention time (s) & $\begin{array}{c}\text { Motor coordination } \\
\text { deficits (\%) }\end{array}$ \\
\hline Vehicle + vehicle + vehicle & $0.926 \pm 0.081$ & $180(180 ; 180)$ & 0 \\
\hline $\begin{array}{c}\text { LCM (3.19) + CBZ (6.25) + } \\
\text { VPA (131.05) }\end{array}$ & $0.919 \pm 0.074$ & $175.5(155.7 ; 180)$ & 12.5 \\
\hline
\end{tabular}

The $1^{\text {st }}$ column lists doses of the studied drugs corresponding to their $\mathrm{ED}_{50 \text { exp }}$ value in the tonic-clonic seizure model. The $2^{\text {nd }}$ column indicates mean muscular strengths (in newtons $[\mathrm{N}] \pm$ S.E.M.) in mice from the grip-strength test. The $3^{\text {rd }}$ column represents median retention times (with $25^{\text {th }}$ and $75^{\text {th }}$ percentiles in parentheses) of the mice in the passive avoidance task. The $4^{\text {th }}$ column indicates percentage of animals with impairment of motor coordination during the chimney test.

\section{Discussion}

In this study we found that the combination of LCM with CBZ and VPA produced antagonistic (infra-additive) interaction in the mouse tonic-clonic seizure model. Unfortunately, the antagonistic interaction entirely disqualified this combination from clinical use so as not to expose patients to ineffective treatment options. The utmost caution is therefore advised for patients receiving this combination of LCM, CBZ and VPA.

Previously, it was reported that the two-drug combination of CBZ with VPA produced an additive interaction in the mouse tonic-clonic seizure model [23]. Unfortunately, at present, there is no available information regarding the type of interaction resulting from the two-drug combinations of LCM with CBZ or VPA in the mouse tonic-clonic seizure model. Although it has been reported that the combinations of LCM with VPA and LCM with CBZ in the mouse $6 \mathrm{~Hz}$-induced seizure model were additive and synergistic, respectively [24]. The $6 \mathrm{~Hz}$ model is thought to be an experimental model of limbic refractory seizures, while in this study we used a model reflecting tonic-clonic seizures in humans. Despite the clear difference in experimental seizure models, the above-mentioned facts allowed us to theoretically expect a favorable combination when combining the three AEDs together (LCM with CBZ and VPA). Unfortunately, instead of expected synergy, an antagonistic interaction occurred among these three AEDs.

To explain the observed antagonistic interaction in the mouse tonic-clonic seizure model, the molecular mechanisms of action of all three drugs should be considered. It can be hypothesized that LCM competitively blocks the anticonvulsant effects produced by CBZ due to the effects of both AEDs on sodium channels or due to a, highly likely, paradoxical effect upon combination of CBZ and LCM, as observed for CBZ and phenytoin [25]. Thus, higher doses of both AEDs are required to provide the same anticonvulsant effects in the mouse tonicclonic seizure model.

On the other hand, we have previously documented that several three-drug combinations, LCM with CBZ and LTG, LCM with CBZ and PB, and LCM with LTG and PB, exerted additive interactions in the mouse tonic-clonic seizure model [6-8]. Since the above-mentioned three-drug combinations were additive in preclinical studies, we determined the magnitude and strength of these combinations by calculating interaction index values. This index, a ratio of $\mathrm{ED}_{50 \text { exp }}$ and $\mathrm{ED}_{50 \text { add }}$ values, allows one to measure the strength of interaction by classifying the combinations as beneficial, neutral and unfavorable [26]. It is widely accepted that interaction index values equal to or lower than 0.7 indicate synergistic interaction, whereas interaction index values equal to or higher than 1.3 reflect infra-additive (antagonistic) interaction. Only values ranging between 0.7 and 1.3 are indicative of additivity [27-29]. In this study, the interaction index value for the combination of LCM with CBZ and VPA was 1.32, whereas the interaction index values for the three-drug combinations ranged from 0.46 to 1.18 in our previously published studies (Table 2). Thus, the interaction index value of 1.32 confirmed that the combination of LCM with CBZ and VPA exerted antagonistic interaction in the mouse tonic-clonic seizure model.

Table 2. Interaction index values for the studied three-drug combinations

\begin{tabular}{|c|c|c|c|}
\hline Combination & Type of interaction & Interaction index & References \\
\hline LCM + CBZ + VPA & infra-additive & 1.32 & [the present study] \\
\hline LCM + CBZ + LTG & additive & 1.05 & {$[8]$} \\
\hline LCM + CBZ + PB & additive & 1.18 & {$[6]$} \\
\hline LCM + LTG + PB & additive & 1.07 & {$[7]$} \\
\hline CBZ + PB + TPM & supra-additive & 0.46 & {$[22]$} \\
\hline PB + PHT + PGB & supra-additive & 0.53 & \\
\hline
\end{tabular}


In this study we also evaluated acute adverse effect potentials of the AEDs in combination. It was found that the combination of LCM, CBZ and VPA produced no acute adverse effects in three behavioral tests (gripstrength, chimney and passive avoidance) used in our study.

An antagonistic interaction between LCM, CBZ and VPA in the mouse tonic-clonic seizure model was observed for the first time and necessitates a warning for patients receiving such a combination due to the fact that a similar interaction may occur in clinical settings. For instance, it has been found isobolographically that the combination of CBZ with LTG was antagonistic in the mouse tonic-clonic seizure model [30], and simultaneously, this combination was highly toxic in patients [31]. Moreover, caution is specifically advised to patients that receive VPA and CBZ and intend to replace one of these AEDs with LCM (as the add-on drug). When replacing one ineffective AED in epileptic patients, there is a general rule that the replaced drug is co-administered with the new one. In such a situation a transient triple therapy (three AEDs) is administered to patients. All three drugs are administered together until the newly introduced AED reaches a steady-state and then the ineffective drug is removed [32].

\section{Conclusions}

1. The mixture of LCM, CBZ and VPA produced an antagonistic (infra-additive) interaction in the tonicclonic seizure model; therefore, it should not be recommended for further clinical trials.

2. A specific warning is required for physicians if they are considering treating epilepsy patients with LCM, CBZ and VPA in combination.

3. LCM should be avoided as a third AED when added to the combination of CBZ and VPA.

\section{References:}

1. Sadr SS, Javanbakht J, Javidan AN, Ghaffarpour M, Khamse S, Naghshband Z. Descriptive epidemiology: prevalence, incidence, sociodemographic factors, socioeconomic domains, and quality of life of epilepsy: an update and systematic review. Arch Med Sci. 2018; 14: 717-724. https://doi.org/10.5114/aoms.2016.60377

2. Stephen LJ, Brodie MJ. Seizure freedom with more than one antiepileptic drug. Seizure. 2002; 11: 349-351. https://doi.org/10.1053/seiz.2002.0711

3. Stephen LJ, Forsyth M, Kelly K, Brodie MJ. Antiepileptic drug combinations - have newer agents altered clinical outcomes?. Epilepsy Res. 2012; 98: 194-198. https://doi.org/10.1016/j.eplepsyres.2011.09.008

4. Deckers CL, Czuczwar SJ, Hekster YA, Keyser A, Kubova H, Meinardi H, et al. Selection of antiepileptic drug polytherapy based on mechanisms of action: the evidence reviewed. Epilepsia. 2000; 41: 1364-1374. https://doi.org/10.1111/j.1528-1157.2000.tb00111.x

5. Blaszczyk B, Miziak B, Czuczwar P, Wierzchowska-Cioch E, Pluta R, Czuczwar SJ. A viewpoint on rational and irrational fixed-drug combinations. Exp Rev Clin Pharmacol. 2018; 11: 761-771. https://doi.org/10.1080/17512433.2018.1500895

6. Kondrat-Wrobel MW, Luszczki JJ. Interaction of three-drug combination of lacosamide, carbamazepine and phenobarbital in the mouse maximal electroshock-induced seizure model - an isobolographic analysis. Health Prob Civil. 2016; 10(1): 55-61. https://doi.org/10.5114/hpc.2016.58209

7. Kondrat-Wrobel MW, Luszczki JJ. Isobolographic additivity among lacosamide, lamotrigine and phenobarbital in the mouse tonic-clonic seizure model. Adv Clin Exp Med. 2018; 27: 881-886. https://doi.org/10.17219/acem/69132

8. Kondrat-Wrobel MW, Luszczki JJ. Additive interaction for three-drug combination of carbamazepine, lacosamide and lamotrigine against maximal electroshock-induced seizures - a type I isobolographic analysis. Eur J Clin Exp Med. 2017; 15: 303-309. https://doi.org/10.15584/ejcem.2017.4.1

9. Luszczki JJ. Isobolographic analysis of interaction for three-drug combination of carbamazepine, phenobarbital and topiramate in the mouse maximal electroshock-induced seizure model. Pharmacology. 2016; 97: 259-264. https://doi.org/10.1159/000444452

10. Makinen J, Rainesalo S, Raitanen J, Peltola J. The effect of newer antiepileptic drugs in combination therapy. Epilepsy Res. 2017; 132: 15-20. https://doi.org/10.1016/j.eplepsyres.2017.02.020

11. Patsalos PN, Perucca E. Clinically important drug interactions in epilepsy: general features and interactions between antiepileptic drugs. Lancet Neurol. 2003; 2: 347-356.

https://doi.org/10.1016/S1474-4422(03)00409-5

12. Luszczki JJ. Third-generation antiepileptic drugs: mechanisms of action, pharmacokinetics and interactions. Pharmacol Rep. 2009; 61: 197-216. https://doi.org/10.1016/S1734-1140(09)70024-6 
13. Lukawski K, Andres-Mach M, Czuczwar M, Luszczki JJ, Kruszynski K, Czuczwar SJ. Mechanisms of epileptogenesis and preclinical approach to antiepileptogenic therapies. Pharmacol Rep. 2018; 70: $284-293$. https://doi.org/10.1016/j.pharep.2017.07.012

14. Tallarida RJ. Drug combinations: tests and analysis with isoboles. Curr Protocol Pharmacol. 2016; 72: 11-19. https://doi.org/10.1002/0471141755.ph0919s72

15. Nevitt SJ, Marson AG, Weston J, Tudur Smith C. Carbamazepine versus phenytoin monotherapy for epilepsy: an individual participant data review. Cochrane Database Syst Rev. 2017; 2: Cd001911. https://doi.org/10.1002/14651858.CD001911.pub3

16. Nolan SJ, Marson AG, Weston J, Tudur Smith C. Phenytoin versus valproate monotherapy for partial onset seizures and generalised onset tonic-clonic seizures: an individual participant data review. Cochrane Database Syst Rev. 2016; 4: Cd001769. https://doi.org/10.1002/14651858.CD001769.pub3

17. Weston J, Shukralla A, McKay AJ, Marson AG. Lacosamide add-on therapy for partial epilepsy. Cochrane Database Syst Rev. 2015; 6: Cd008841. https://doi.org/10.1002/14651858.CD008841.pub2

18. Franco V, French JA, Perucca E. Challenges in the clinical development of new antiepileptic drugs. Pharmacol Res. 2016; 103: 95-104. https://doi.org/10.1016/j.phrs.2015.11.007

19. Kocharov SL, Panosyan HA, Marzeda P, Wroblewska-Luczka P, Kochman E, Wlaz A, et al. Anticonvulsant potency of 10 various p-isopropoxyphenylsuccinimide derivatives in the maximal electroshock-induced seizure threshold model in mice. Health Prob Civil. 2017; 11(3): 195-201. https://doi.org/10.5114/hpc.2017.70010

20. NRC. Guide for the care and use of laboratory animals. 8th edition. Washington (DC): National Academies Press; 2011.

21. Litchfield JT Jr, Wilcoxon F. A simplified method of evaluating dose-effect experiments. J Pharmacol Exp Ther. 1949; 96: 99-113.

22. Luszczki JJ, Mazurkiewicz LP, Wroblewska-Luczka P, Wlaz A, Ossowska G, Szpringer M, et al. Combination of phenobarbital with phenytoin and pregabalin produces synergy in the mouse tonic-clonic seizure model: an isobolographic analysis. Epilepsy Res. 2018; 145: 116-122. https://doi.org/10.1016/j.eplepsyres.2018.06.003

23. Bourgeois BF. Anticonvulsant potency and neurotoxicity of valproate alone and in combination with carbamazepine or phenobarbital. Clin Neuropharmacol. 1988; 11: 348-359. https://doi.org/10.1097/00002826-198808000-00003

24. Shandra A, Shandra P, Kaschenko O, MatagneA, StohrT. Synergism oflacosamide with established antiepileptic drugs in the 6-hz seizure model in mice. Epilepsia. 2013; 54: 1167-1175. https://doi.org/10.1111/epi.12237

25. Thomas EA, Petrou S. Network-specific mechanisms may explain the paradoxical effects of carbamazepine and phenytoin. Epilepsia. 2013; 54: 1195-1202. https://doi.org/10.1111/epi.12172

26. Tallarida RJ. The interaction index: a measure of drug synergism. Pain. 2002; 98: 163-168. https://doi.org/10.1016/S0304-3959(02)00041-6

27. Gennings C. Economical designs for detecting and characterizing departure from additivity in mixtures of many chemicals. Food Chem Toxicol. 1996; 34: 1053-1058. https://doi.org/10.1016/S0278-6915(97)00074-4

28. Luszczki JJ, Czuczwar SJ. Preclinical profile of combinations of some second-generation antiepileptic drugs: an isobolographic analysis. Epilepsia. 2004; 45: 895-907. https://doi.org/10.1111/j.0013-9580.2004.05104.x

29. Berenbaum MC. What is synergy? Pharmacol Rev. 1989; 41: 93-141.

30. Luszczki JJ, Czuczwar M, Kis J, Krysa J, Pasztelan I, Swiader M, et al. Interactions of lamotrigine with topiramate and first-generation antiepileptic drugs in the maximal electroshock test in mice: an isobolographic analysis. Epilepsia. 2003; 44: 1003-1013. https://doi.org/10.1046/j.1528-1157.2003.10003.x, https://doi.org/10.1046/j.1528-1157.2003.32702.x

31. Besag FM, Berry DJ, Pool F, Newbery JE, Subel B. Carbamazepine toxicity with lamotrigine: pharmacokinetic or pharmacodynamic interaction?. Epilepsia. 1998; 39: 183-187. https://doi.org/10.1111/j.1528-1157.1998.tb01356.x

32. Riva R, Albani F, Contin M, Baruzzi A. Pharmacokinetic interactions between antiepileptic drugs. Clinical considerations. Clin Pharmacokin. 1996; 31: 470-493. https://doi.org/10.2165/00003088-199631060-00005 